\title{
Development of Multimedia Learning Geography Based on Adobe Flash to Increase Students' Curiosity
}

\author{
Wahid Yuda Rejeki* and M. Mukminan \\ Departement of Geography Education, Yogyakarta State University, Jl. Colombo No.1, \\ Karang Malang,Yogyakarta, 55281, Indonesia \\ *Corresponding Author : yudharejeki@gmail.com
}

Received 7 December 2019/ Revised 10 October 2020 / Accepted 23 November 2020/ Published 30 December 2020

\begin{abstract}
This study aimed to analyze: (1) The needs of multimedia Adobe Flash-based towards geographic learning, (2) Geography multimedia learning of Adobe Flash-based to increase students' curiosity, and (3) The feasibility of utilizing geography multimedia based on Adobe Flash-based learning using ADDIE method. The needs of multimedia learning assessment data were collected through questionnaires towards respondents ( 2 teachers and 32 students). Meanwhile, regarding the feasibility of multimedia geography learning to increase students' curiosity, data were gathered both by tests and questionnaires. The feasibility assessment was performed with expert validation instruments and student assessments. The data analysis tool utilized was one-way ANOVA. The study results as follows: (1) Students needs of geography multimedia learning based on Adobe Flash, (2) For effectiveness rate of multimedia and treatment, Fcount $=20,875>$ Ftable $=3.99$, indicates that geography learning based on Adobe Flash is can escalate students' curiosity, (3) Based on experts judgments and the students' assessments, it could be concluded that the geography multimedia learning based on Adobe Flash is $91.4 \%$, hence it is very suitable to be implemented. Multimedia learning based on Adobe Flash geography has increased students' curiosity and feasible to implement.
\end{abstract}

Keywords: Adobe Flash; Geography; Multimedia; Curiosity

\section{Introduction}

Education serves to improve the ability and to establish the national honour and custom in term of intellectual aspect that aims to develop students potential in order to become whole human beings, have faith, valuable character, healthy, skilled, creative, independent, and being democratic and responsible citizens. Indah et al. (2018), stated that education plays a crucial role in Indonesia in improving the quality of human resources.

Learning is the process in creating a relationship between something (knowledge) that has been known and something (knowledge) that is unfamiliar Al-Tabany (2014). Based on this concept, the learning dimension contains several elements, namely: (1) relationship 
establishment; (2) things (knowledge) that have been acknowledged; and (3) things (knowledge) that are unknown. Thereby, in the sense of learning, it is inseperable towards things that are completely unknown (zero), but it relates two existing knowledge with new ones. Learning is a mental process. Learning emphasizes the process of acquisition and finding knowledge through interactions between individuals and the environment. In term of learning, the educational process in schools not only emphasizes the accumulation of knowledge but also emphasizes the priority of students ability to construct their own knowledge (Sanjaya, 2016). The achievements of these objectives are inseparable towards all components that integrate upon education, which the components are interrelated. Mukminan (2018), stated that academic learning activities go effectively and achieve the expected goals once efforts are being made to create a conducive learning climate to establish an effective education system. Learning climate has become social-academic beliefs, habits, and behaviour that generate academic custom. Academic climate might be developed through decent interaction between teachers, students, appreciation for students' achievement, being supportive of student behaviour, discipline, collaborative leadership, a collaboration between teachers, professional system development, and goals that will be achieved altogether. A constructive learning environment according to Schunk (2012) provides issues which are significantly relevance to students, organizing learning material key concepts, investigating and appreciating students' perspectives, implementing curriculum in order to take into account students' perspective, and assessing student learning in the context of teaching. Pang \& Runesson (2019), stated that learning focuses on a particular learning object, namely abilities, skills or values that are expected to be achieved by students. The major focus of learning is determining how students could be supported to adapt towards certain learning objects in a proper method. One of which is multimedia learning.

According to Arsyad (2002), multimedia learning utilization as an integral part of learning within the classroom or as a primary tool of direct learning shows a positive impact on learning. Another explanation according to Harjanto (2011) defined learning multimedia as everything that could be used to transmit information or lesson content, to stimulate the mind, feelings, attention, and students abilities. Hence, multimedia is capable to encourage the process of teaching and learning. Media is the learning resource, thus in broad context learning media could be associated towards humans, objects or events that enable students to obtain knowledge and skills (Agustien et al., 2018).

According to the interviews performed with geography teachers at MA Sunan Pandanaran, multimedia learning of geography utilized by teachers was tend to be 
homogenous. The teachers were accustomed to conventional learning. School only provided the textbooks as the sources of basic learning and student worksheets as support. The books in term of texts have the tendency to be informative. Thus, textbooks do not usually attract the students' interests during the learning process. The textbooks provided were also limited numbers as one book was shared for two students. Multimedia learning was also limited to Power Point or video. The lack of variety in multimedia learning enhances learning to be less attractive, that will have an impact on students' interest and curiosity in learning. Curiosity is a conditional aspect of students development. Each knowledge will bring a curiosity towards things. The curiosity will raise in more depth sense and eventually the desire arises for the students to be able to master it. Thereby, it requires an effective, innovative and attractive multimedia learning of geography to assist students to embrace geography material. Regarding the results of observations and interviews obtained, it is necessary to develop a learning media that could escalate the students' interests in learning. A learning media that is rarely applied in learning does not require internet of the network. It can be operated in various types of computer or laptop with any specifications but students could still interact actively.

In order to establish effective and interesting learning conditions, depends on instructional media engagement (Atapukang, 2016). Thus, it is not surprising that media engagement is one of the factors determining students' achievement. This occurs since learning media proposes significant effect towards motivation, interests, and capable in visualising objects that helps students in learning. Ones who can think critically are those who obtain high curiosity, extensive experience, full of confidence, and open-minded (Indah et al., 2018). Multimedia learning acts as a bridge between students and teachers to exchange messages between the teacher as the sender and the student as the recipient.

Multimedia is a combination of digital technology for managing text, photos, graphic arts, sound, animation, and video (Vaughan, 2011). The combination of all the elements to generate something and can be operated anywhere is known as interactive multimedia. The development of computer technology is growing rapidly. And then the role of Power Point (PPT) slides could be replaced by several types of applications, one of the software that can be used is Adobe Flash (Istiono, 2008). Adobe Flash is a professional standard for generating web animations, graphics, audio, and video processing capabilities and also accommodating materials into an animation called a movie. Adobe Flash as a tutorial model is an application that supports the development of multimedia learning, with various features available enable developers to be creative to create high-quality learning media (Prasetyo \& Ginting, 2019). 
Hence, it will likely be able to improve students' learning understanding. There are several advantages, the final file (after publishing) is very low and lightweight as it is easy to operate and the results can be applied to all computer specifications. Adobe Flash CS6 is the basis for developing the latest simulation model of Computer Assistance Instruction (CAI) learning programs (Hidayati, 2017).

Critical thinking skills have a solid connection towards curiosity (Zetriuslita et al., 2017). This attitude serves as the initial step of skill. Students' curiosity at the stage of current phenomena is included in the excellent category which can be identified by asking questions frequently, persistent, enthusiastic and actively observing activities to figure new information related to phenomena or problems being faced (Ulva et al., 2017). Teaching strategies and levels of curiosity likely affect achievement in reading comprehension (Gurning \& Siregar, 2017). It was concluded by Hsee \& Ruan (2016), that curiosity encourages people to search for information that provides not only immediate pleasure or long-term benefits, but has a genuine desire to resolve curiosity.

The educational environment must offer students the opportunity to develop 21 stcentury skills in the age of computerization. The presence of computers in the sense of education provides a very important impact, especially for the teaching and learning process for instance, the utilization multimedia learning technology (Arifin et al., 2018). Utilization of multimedia technology as a learning medium could support teaching and learning activities become more interesting and enjoyable. Ghani \& Daud (2018) argued that ADDIE is one of the most popular research models among all instructional and is constantly updated and implemented in many large organizations. Each phase of the model possesses different procedural steps.

The issues being investigated of this research are as follows: (1) How the needs of multimedia in term of Adobe Flash-based geography learning, (2) How the multimedia of Adobe Flash-based of geography learning increase students' curiosity, and (3) How is the feasibility of utilizing multimedia utilization of Adobe Flash-based of geography learning engaging the ADDIE method.

There are some significances of this research, as namely: (1) assisting students to understand and fathom geography learning materials, and (2) provide real insight for teachers relating the importance of using various learning resources, such as multimedia of geography learning that might be developed independently by the teacher in the future. The purposes of this research are (1) Identify the needs of multimedia Adobe Flash-based geography learning, (2) Generate Multimedia of Adobe Flash-based geography learning to increase 
students' curiosity, and (3) Investigate the feasibility of utilizing multimedia based on Adobe Flash-based geography learning using ADDIE method.

\section{Methods}

The method utilized in developing multimedia based on Adobe Flash geography is research and development. The study was conducted at MA Sunan Pandanaran. Instructional design models could assist plan establishment and implement a curriculum to meet learning needs (Cheung, 2016). The model employed in this study was ADDIE. Branch (2009) explained ADDIE stands for Analyze, Design, Develop, Implement and Evaluation. ADDIE has been widely applied in learning environment that has been designed suitable for learning objectives. This statement is supported by Sugiyono (2015) stated that ADDIE is an abbreviation of the development stage, which starts from the Analysis, Design, Development or Production, Implementation or Delivery, and Evaluations stages to generate learning products in the form of learning multimedia that could be utilized within the learning process. The procedures of the multimedia product development model in this stage are namely :

a) Analysis Phase, the preliminary study include observations and interviews to investigate and identify the issues upon learning activities process.

b) Design Phase, at this stage, it is used as a reference in designing multimedia of geography learning engaging literature studies and needs analysis which is then performed in detail development.

c) Development Phase, development stage as a merger between planning and development phases of products that composed of activities that determine the objectives, the parties involved, development, formulate forms of participation, work procedures and due diligence.

d) Recognizing Implementation, at this stage, after the product is being validated, the product in the form of multimedia development of geography learning is implemented in the classroom learning in order to investigate the increase of student learning outcomes.

e) Evaluation Phase, at this stage, the product is being evaluated as a revised form derived based on implementation. If deficiencies are still found, an evaluation is necessary.

ADDIE model is one of the most commonly used models in learning to design or generate a product (Aldoobie, 2015). This model significantly assists designers to develop a variety of content such as instructional designs making by the teachers. The ADDIE model is not only based on theory and research but also various experiences and applications (Dick et $a l ., 2015)$. The feature of the ADDIE model could be related to understanding a practical 
recipe book. Starting with using recipes from one's kitchen, own ingredients, and a little touch of their own work will result in a different product. Recipes can still be changed by different steps and replacing ingredients, even though the initial stages are still the same, namely analysis, design, development, implementation, and evaluation.

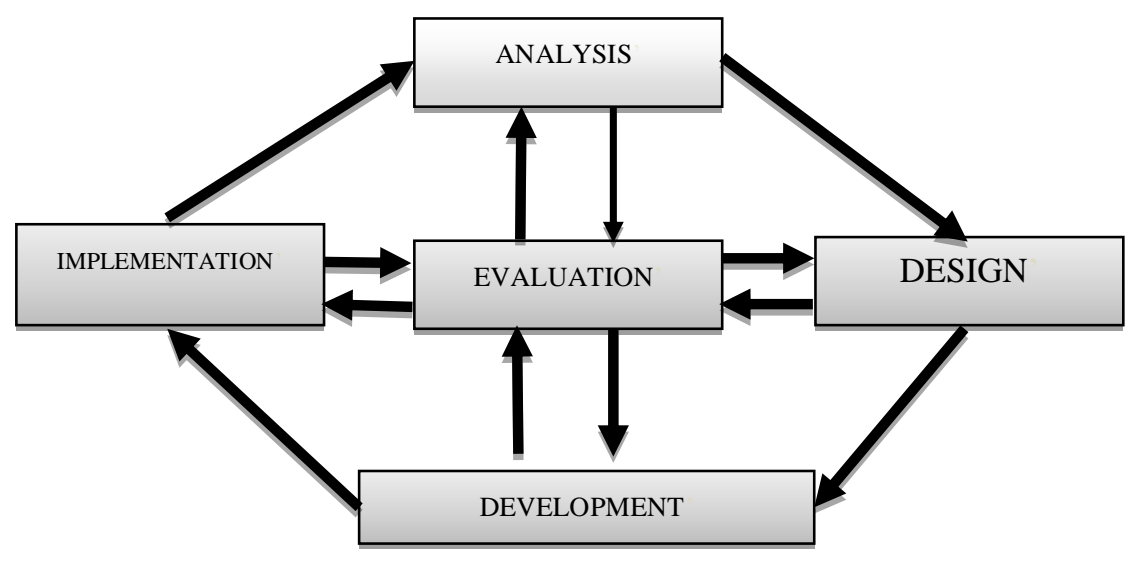

Figure 1. ADDIE model (Dick et al., 2015)

ADDIE model is an abbreviation to describe the process-based approach to develop learning content or product derived from instructional design (Hess \& Greer, 2016). The ADDIE model can be summed up as a colloquial term to describe a system in thematic design, one of which is the development of virtual learning (Molenda, 2015). The development of learning multimedia using Adobe Flash is expected to escalate students' curiosity. Curiosity is a conditional aspect of students' development. Every knowledge brings up one's curiosity about something new.

Curiosity has a solid relation towards the significance of multimedia or technology either supporting or even diminishing (Arnone et al., 2011). Curiosity is the desire for the new information or experience as the result of a new environment either driven by something that is unknown or a dynamic environment, hence that feeling of satisfaction and dissatisfaction emerge. Curiosity behaviour can be connected to a natural human impulse to learn and develop (Nugroho, 2019). Curiosity is an aspect of motivation that has the significant potential to improve the quality of student learning (Pluck \& Johnson, 2011). Curiosity is a form of intrinsic motivation in organizing active learning to explore things that were not previously known (Oudeyer et al., 2016). Curiosity is one of the main bases of an education that is efficient, fun, and could foster motivation, thus it could be a solution to the challenges of education in the 21 st century. 
in terms of the attitude of curiosity, curiosity is one of the scientific attitudes (Zetriuslita et al., 2019). Individuals who are passionate to figure about science, are productive, open-minded, entrepreneurs, problem solvers, and lifelong learning, need to be trained and new needs that arise in education must be met (Erdogan \& Ciftci, 2017). The evaluation phase was performed after the previous stages were completed. Then the final product, namely the development of multimedia learning based on Adobe Flash geography. The trial was conducted in two stages, namely small group trials and field trials, small group trials consisted of 6 students and field trials involved one class.

One-way ANOVA was used to analyze the data. The feasibility of multimedia learning of geography learning material is recognized through an ability test of 32 students from XI IIS 1 MA Sunan Pandanaran. This research type is development research (multimedia development) conducted at MA Sunan Pandanaran. Quantitative data in this study were obtained from questionnaire results questioning the multimedia needs of Adobe Flash-based geography learning to identify the level of needs and pretest-posttest to asssess students' curiosity. Qualitative data were collected based on content experts, media experts, and two geography subject teachers to assess the quality and feasibility of Adobe Flash-based geography learning multimedia to be developed. The subjects of this study were 32 students of class XI IIS 1. The design of this study utilized the ADDIE model. The ADDIE model has 5 stages, namely: (1) Analyze, (2) Design, (3) Development, (4) Implementation, and (5) Evaluation. Data collection techniques were conducted through observation, documentation, and questionnaires. Validation was conducted by experts and product trials were also performed. The experts employed validation assessment of material and media.

\section{Results and Discussion}

\subsection{Multimedia Needs}

Based on the study results, it can be seen that the students who answered the most on the first statement were always interested that every geography lesson took place as many as 20 students (62\%) decided it. Detailed multimedia and the feasibility of it could be used as a source of learning were answered by 12 students (37\%) with answers sometimes feeling pleased. Teaching materials that provided information upon surrounding were answered by 18 students $(56 \%)$ with always pleasing answers.

Teaching materials that were being visualized or displayed on electronic multimedia, encouraged 21 students to answer that they were always glad (66\%). In the statement of the need for electronic teaching materials, there was 19 students answer (59\%) who were always 
needed electronic teaching materials. The statement at the next point was about the diversity of learning resources used in learning. As many as 25 students (78\%) answered that they were always glad. In the final statement was if multimedia learning directed how the work, pictures, or material that was more detailed or concrete. Most students answered that they were always pleased as many as 19 students (59\%).

\subsection{Multimedia Development}

Electronic multimedia was developed using the ADDIE development model. This model composes of several steps, including analysis, design, development, implementation, and evaluation. However, this research was mainly conducted as far as the developmental stage. The first stage of this research was analysis. The analysis was performed with students needs analysis and literature review. The literature review was intended to collect theoretical foundations relating to the research goal upon the development of geography multimedia based on Adobe Flash. A needs analysis was implemented to identify students' needs for learning resources that would be engaged in the learning process. Students' needs were obtained based on the questionnaire with 7 statement items. The questionnaire was distributed to 32 students, it was identified that 19 students (59\%) answered that they referred to electronic teaching material rather than printed material.

The second stage was the design. Learning design is a basic foundation for educators and students in achieving better learning outcomes (Dewi, 2018). Educators in completing their duties need to prepare learning activities thoroughly. Through learning, the design provides short-term and long-term work references. The design was based on needs analysis and interviews conducted toward geography teachers. The initial product design stage, the Adobe Flash application was applied to create a multimedia geographic design with natural resource teaching materials. The final result of this product design activity was geography multimedia learning on landslide natural disaster topic.

After completing the initial design, the next step must be performed was determining the main competencies, basic competencies, indicators, and learning objectives. The developed learning multimedia was integrated with the 2017 curriculum and Adobe Flash application, thus learning places more emphasized on the process and the processes that were purposeful for students. The initial design of multimedia geography learning based on Adobe Flash is illustrated in figure 2, figure 3 , figure 4 , figure 5 , and figure 6. 


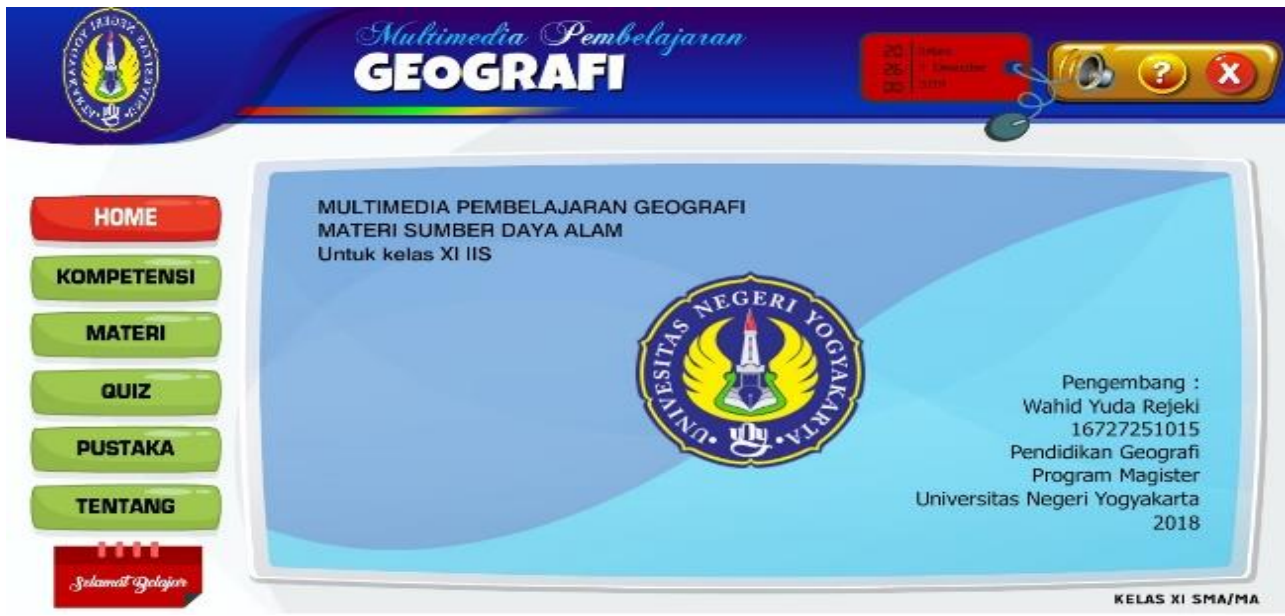

Figure 2. The example of media preview
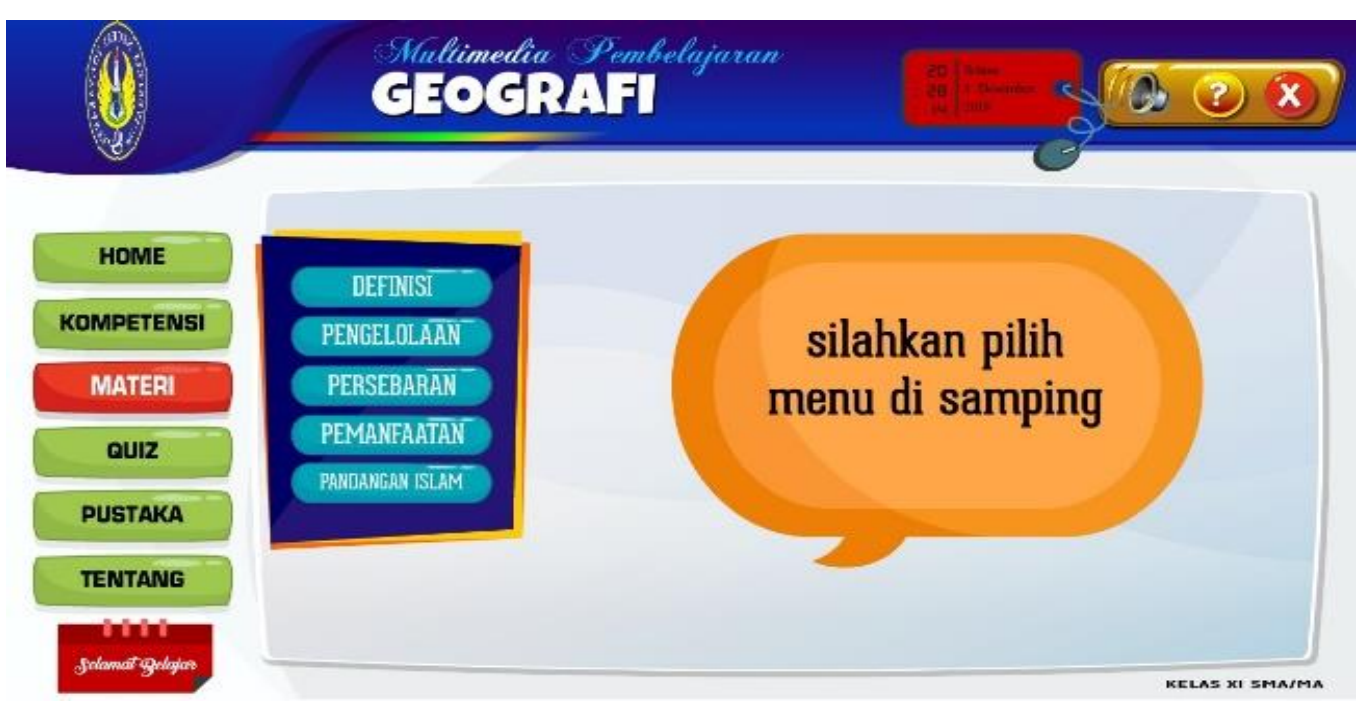

Figure 3. The example displays of the media menu

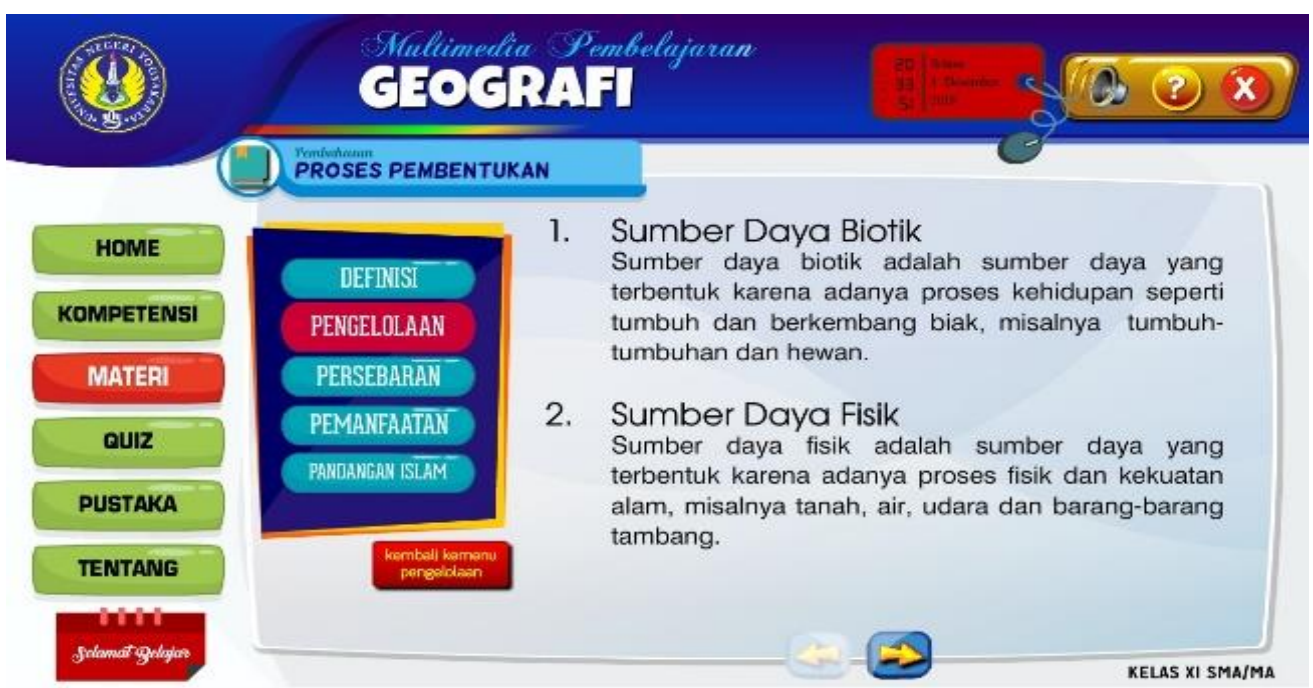

Figure 4. The example the material display 


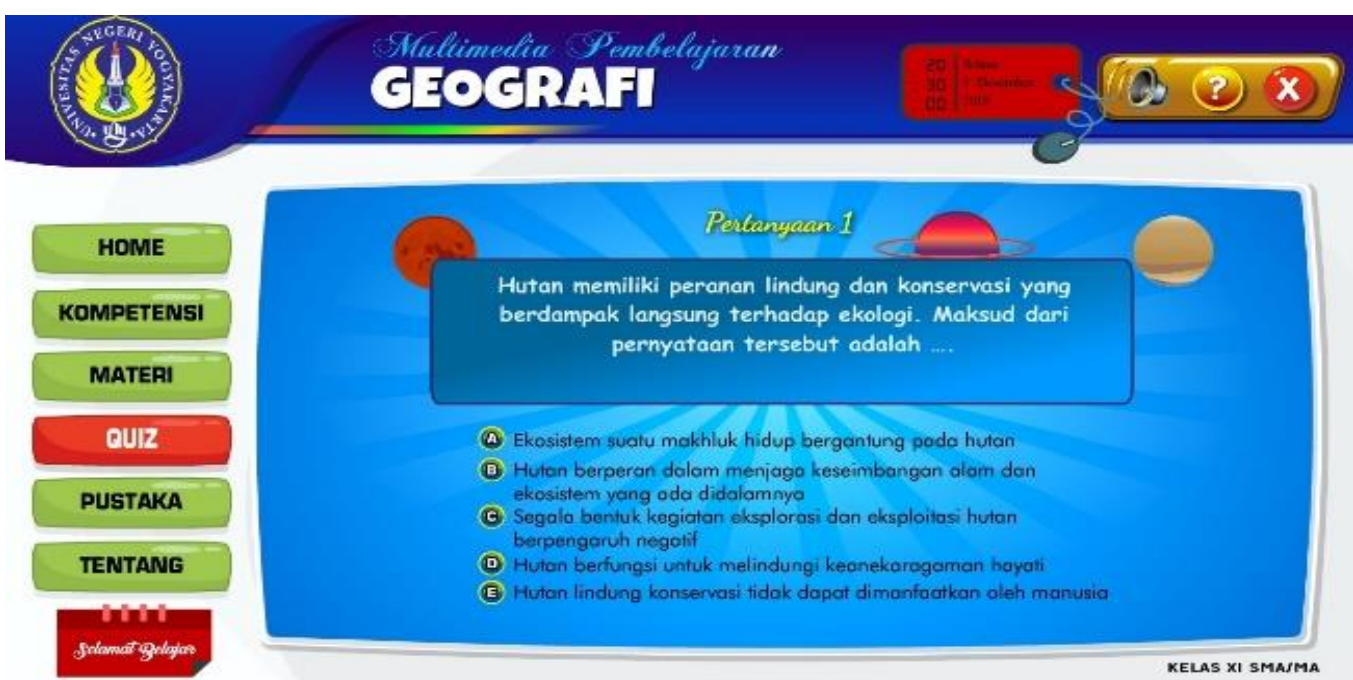

Figure 5. The example of quiz display
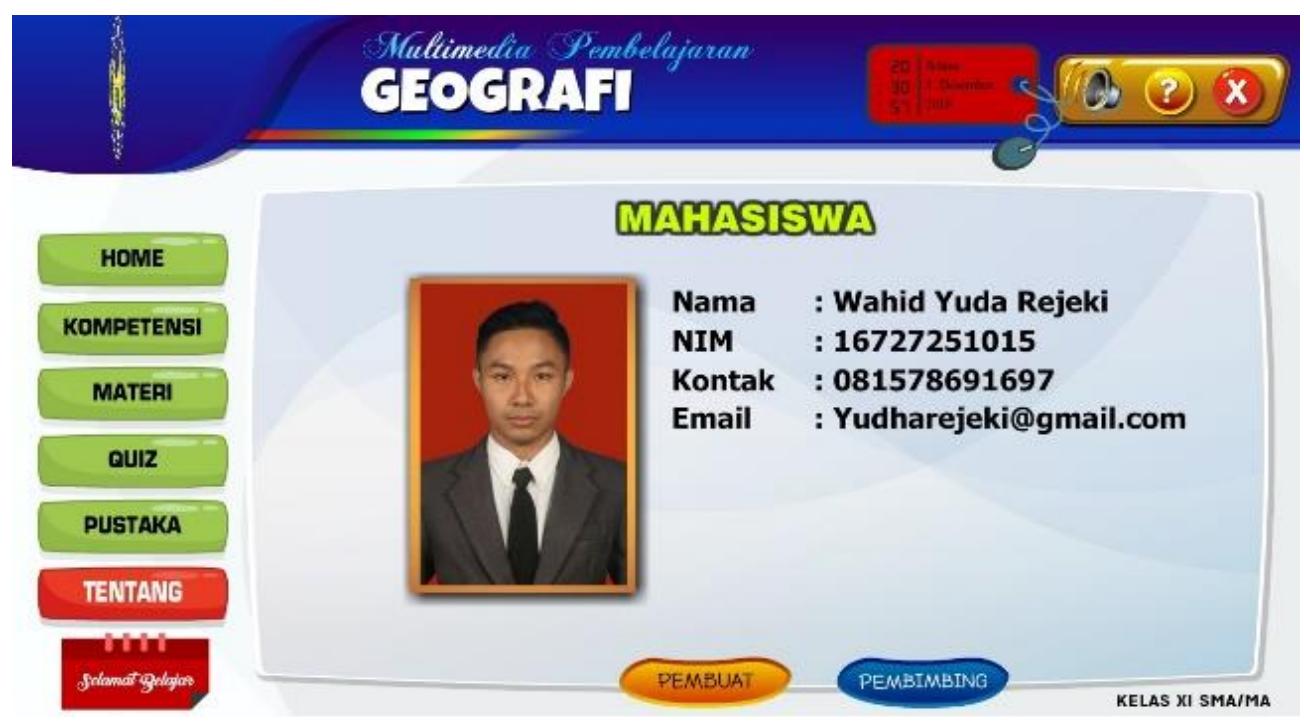

\section{MATASISWA}

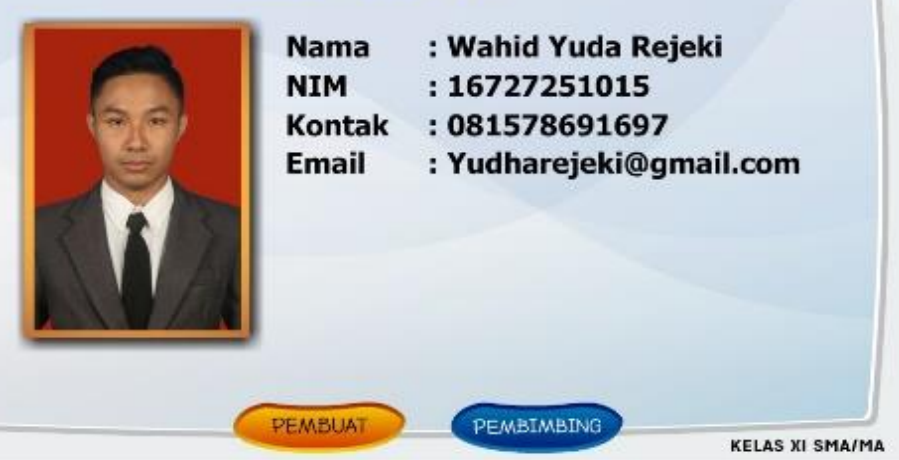

Figure 6. The example display of researcher identity

Once the design phase was finished, the next stage was the validation stage. The result of multimedia learning validation was $85 \%$, means it is suitable to be engaged in geography learning. After being validated, the learning multimedia was tested towards 6 students of class XI IIS 1 MA Sunan Pandanaran. Then, in order to identify the students response, a closed questionnaire containing 10 items was employed. The next stage was analyzing the students' responses. The results showed the average score of students' responses with 10 items of questionnaire achieved $91.4 \%$ means it could be considered feasible.

Adobe Flash based on geographic multimedia was developed using the research development stages, mainly referring to the ADDIE model. The first stage is the analysis phase. At this stage, researchers conducted a literature analysis, field analysis, and students' needs. Students' needs were identified through a questionnaire consisting of 7 items about 
learning needs. The questionnaire was constructed using the Linkert scale. Based on the analysis, it is concluded that students need electronic teaching materials.

The second stage is the design stage. Multimedia geography was designed utilizing the Adobe Flash application as this application is relatively convenient to operate. Adobe Flashbased geography multimedia was equipped with title display, menu display, and content material discussing the utilization of the natural resources integrated with images, maps, videos, quizzes, answer keys, discussions, and the author's identity. The learning multimedia development has been integrated with the 2017 curriculum.

The third step is development. At this stage, validation was utilized by the experts group and the product was tested on a small group of students. Furthermore, learning multimedia was tested into small groups consisting of 6 students. Based on the results of validation and test, Adobe Flash-based multimedia geography is considered suitable to be utilized within the learning process.

\subsection{The Enhancement of Curiosity}

Students' ability tests were conducted in pre-test and post-test (Table 1). The evaluation data of students' interest had changed their learning outcomes by utilizing Adobe Flash-based geography learning multimedia can be seen as follows. This is relevant with Peljko \& Marič (2016), that curiosity influences innovation. There is a feeling of being attracted to situations in which there is learning potential. There is a desire to acquire new experiences to figure what is happening and to investigate how other people react. Curiosity is defined as someone's need or desire to draw to questions or things that occur in daily life (Arditama et al., 2018). Multimedia learning is the media engages in learning activities in order to stimulate students' thoughts, feelings, interests, and attention, thus the educational communication interaction process between the teacher (or media maker) and students could take place appropriately and efficiently (Wahyudi et al., 2017).

Table 1. Student Learning Data

\begin{tabular}{ccc}
\hline Description & Pre-Test & Post-Test \\
\hline Total & 1445 & 2335 \\
Mean & 43,79 & 70,76 \\
Min & 35,00 & 60,00 \\
Max & 60,00 & 82,50 \\
Median & 42,50 & 72,50 \\
Modus & 42,5 & 72,5 \\
Range & 25,00 & 22,50 \\
\hline
\end{tabular}


The data was then calculated using the normality and homogeinity test with SPSS 19 program. The normality test table can be seen in table 2 .

Table 2. Normality Test

\begin{tabular}{ccc}
\hline Description & Pre-Test & Post-Test \\
\hline Statistic $(\mathrm{L})$ & .148 & .148 \\
Df & 32 & 32 \\
Sig. & .235 & $.0,56$ \\
$\mathrm{~L}_{\text {tabel }}(0,05,33)$ & 0,156 & - \\
$\mathrm{L}_{\text {tabel }}(0,05,32)$ & - & 0,156 \\
Description & $\mathrm{L}_{\text {liliefors }}<\mathrm{L}_{(\mathrm{a}, \mathrm{n})}$ & $\mathrm{L}_{\text {liliefors }}<\mathrm{L}_{(\mathrm{a}, \mathrm{n})}$ \\
Sig. & $>0,050$ & $>0,050$ \\
Conclusion & Normal & Normal \\
\hline
\end{tabular}

Based on the normality test using SPSS 19, the data obtained above. Lilliefors Significance Correction output shows normality of pre-test and post-test with significancy of test $(\mathrm{a}=0,05)$ that means normal. This shows that Sigcount $>0,05$ dan $\mathrm{L}$ count $<\mathrm{L}$ table.

Referring to analysis results using Levene test of SPSS 19 indicates outcome results could be seen in table 3 .

Table 3. Homogeneity Test

\begin{tabular}{cc}
\hline Class & Pre-Test and Post-Test \\
\hline Leene Statistic $(\mathrm{F})$ & 1,014 \\
Dfl & 1 \\
Df2 & 61 \\
Levene's Sig. & .318 \\
$\mathrm{~F}_{(0,05,1.70)}$ & - \\
$\mathrm{F}_{(0.05,1.61)}$ & 4.00 \\
Sig & $>0,050$ \\
Conclusion & $\mathrm{H}_{\mathrm{o}}$ accepted \\
\hline
\end{tabular}

Based on homogeneity test statistics using SPSS 19 generates output as shown in table 3. The interpretation was performed by selecting one of the statistics, the statistics used for this study were based on averages (Based on Mean). Referring to statistics Based on Mean obtained significance $>0.05$. Thus, it can be concluded that students' spatial ability data is homogeneous.

Data analysis engaged to test the hypothesis in this study is the statistical parametric test (One-Way ANOVA). The results of ANOVA upon the ability of students who were implemented with Adobe Flash multimedia learning towards students curiosity could be seen in table 4. 
Table 4. ANOVA calculation

\begin{tabular}{cc}
\hline Statistic $(\mathrm{F})$ & 20,875 \\
\hline Df & 62 \\
Sig. & 0,000 \\
$\mathrm{~F}_{\text {tabel }}(0,05)$ & 3,99 \\
$\mathrm{~F}_{\text {tabel }}$ & $\mathrm{F}_{\text {hitung }}>\mathrm{F}(0,05 ; 62)$ \\
Sig & $0,000<0,050$ \\
Conclusion & $\mathrm{H}_{0}$ rejected \\
\hline
\end{tabular}

Based on the ANOVA One-Way calculation shows that Adobe Flash multimedia application is significant upon students' curiosity in with landslides topic. Based on significance calculation, the value (sig.) of the model is $0.000<0.05$ (alpha), which means that the application of Adobe Flash learning multimedia in learning affects students curosity. Referring to the treatment the effectiveness, the value calculation of $\mathrm{F}$ obtained Fcount = 20,875 was consulted with the $\mathrm{F}$ table with a significance level of 0.05 obtained Ftable $=$ 3.99. as $\mathrm{F}$ count $=20,875>\mathrm{F}$ table $=3.99$. This means that geography learning utilizing Adobe Flash multimedia increases students' curiosity.

Development of geography learning multimedia through research development stages that refers to the ADDIE models. The first stage is the analysis phase. At this stage, the researcher analyzed the needs of learners and literature. Learning needs were identified using the questionnaire composed of 7 statements in terms of electronic teaching materials needs of 32 students. The questionnaire results were analyzed using a Likert scale. Based on the analysis results, it is obtained that $59 \%$ of students response were preferred to electronic teaching materials than to printed material. This is in line with Rosmaiyadi (2017) that during the learning process, every student has different characteristics between one and another. Some of the characteristics of these students that need to be considered during the teaching and learning process are the learning style and how students think.

The second stage is the design. Geography learning multimedia is designed utilizing the Adobe Flash application as it could be easily operated. This is in line with Juminah et al., (2019), the application of Adobe Flash can be performed in a computer at laboratory or laptop. Hidayati (2017) added that Adobe Flash is a vector-based animation program, which has been widely used by animators to create various animations. The developed geography learning multimedia contains natural resource materials that integrated with the 2017 curriculum. Geography learning multimedia based on Adobe Flash is equipped with basic competencies, learning materials, quizzes, and developer identities. 
The third step is development. At this stage, validation performed by 2 expert groups namely the media expert team and the content expert. Based on the validation results it is identified that the product achieved a score of $85 \%$ means it is feasible to be developed. Furthermore, geography learning multimedia were tested on small groups of 6 students. Based on the validation results and trial, geography learning multimedia based on Adobe Flash is considered suitable to use in the learning process by $91.4 \%$.

Geography learning multimedia based on Adobe Flash is then conducted to analyze students' curiosity. The feasibility of geography learning multimedia based on Adobe Flash to increase curiosity is applied to 32 students applying pretest and posttest. Data analysis was engaged with One-Way ANOVA. Referring to the calculations shows that geography learning multimedia based on Adobe Flash utilization increases students' curiosity. This is in line with Zetriuslita et al. (2017), curiosity is a phenomenon that is usually characterized by efforts made to obtain and investigate something that leads to enthusiasm for learning, figure out and investigating. Adobe Flash is one of the solutions to scale down the monotonous learning. The same thought also expressed by Atapukang (2016) stated that learning integrating with interesting media will be a determinant of student success.

\section{Conclusion}

There is need of students towards multimedia learning geography based on Adobe Flash, multimedia learning based on Adobe Flash geography has increased students curosity, and multimedia Adobe Flash-based geography learning is feasible to implement. Suggestions that can be given for further research is the development of multimedia with a more creative and attractive appearance for students. Then, Adobe Flash-based geography learning multimedia is expected to be employed with other gadgets such as smartphones or tablets.

\section{Conflict of Interest}

The authors declare that there is no conflict of interest with any financial, personal, or other relationships with other people or organizations related to the material discussed in the article.

\section{References}

Agustien, R., Umamah, N., \& Sumarno, S. (2018). Pengembangan Media Pembelajaran Video Animasi Dua Dimensi Situs Pekauman di Bondowoso Dengan Model Addie Mata Pelajaran Sejarah Kelas X IPS. Jurnal Edukasi, 5(1), 19. https://doi.org/10.19184/jukasi.v5i1.8010. 
Al-Tabany, T. I. B. . (2014). Mendesain Model Pembelajaran Inovatif, Progresif, dan Kontekstual. Jakarta: Prenadamedia Group.

Aldoobie, N. (2015). ADDIE model. American International Journal of Contemporary Research ADDIE, 5(3), 68-72.

Arditama, A. Y., Wardani, S., Purwanti, E., \& Hindarto, N. (2018). Storybook Influence on Science Concept Comprehension Through Curiosity of Fifth Grade Elementary School Student. Journal of Primary Education, 7(1), 1-9.

Arifin, R. W., Septanto, H., \& Wignyowiyoto, I. (2018). Pengembangan Media Pembelajaran Berbasis Video Animasi Dengan Model ADDIE Dalam Kegiatan Pembelajaran Blended Learning. Information Management For Educators And Professionals. Journal Of Information Management, 2(2), 179-188.

Arnone, M. P., Small, R. V., Chauncey, S. A., \& McKenna, H. P. (2011). Curiosity, interest and engagement in technology-pervasive learning environments: A new research agenda. Educational Technology Research and Development, 59(2), 181-198. https://doi.org/10.1007/s11423-011-9190-9.

Arsyad, A. (2002). Pokok-Pokok Manajemen. Yogyakarta: Pustaka Pelajar.

Atapukang, N. (2016). Kreatif Membelajarkan Pembelajar Dengan Menggunakan Media Pembelajaran Yang Tepat Sebagai Solusi Dalam Berkomunikasi. Jurnal Media Komunikasi Geografi, 53(9), 45-52. https://doi.org/10.1017/CBO9781107415324.004.

Branch, R. B. (2009). Instructional Design: The ADDIE Approach. London : Springer Science \& Business Media.

Cheung, L. (2016). Using the ADDIE Model of Instructional Design to Teach Chest Radiograph Interpretation. Journal of Biomedical Education, 2016, 1-6. https://doi.org/10.1155/2016/9502572.

Dewi, L. (2018). Learning Design Using Addie Approach To Improve Students ' Critical Thinking Skills in Becoming Ethical Librarians. Jurnal Edulib, 8(1).

Dick, W., Carey, L., \& Carey, J. O. (2015). The systematic design of instruction, eight edition (8th ed.). London: Pearson Education Ltd.

Erdogan, I., \& Ciftci, A. (2017). Investigating the Views of Pre-Service Science Teachers on STEM Education Practices. International Journal of Environmental and Science Education, 12(5), 1055-1065.

Ghani, M. T. A., Daud, W. A. A. W. (2018). Adaptation of ADDIE instructional model in developing educational website for language learning. Global Journal Al-Thaqafah, $8(2), 7-16$.

Gurning, B., \& Siregar, A. (2017). The Effect of Teaching Strategies and Curiosity on Students' Achievement in Reading Comprehension. English Language Teaching, 
10(11), 191. https://doi.org/10.5539/elt.v10n11p191.

Harjanto. (2011). Perencanaan pengajaran (8th ed.). Jakarta: Rineka Cipta.

Hess, A. K. N., \& Greer, K. (2016). Designing for Engagement : Using the ADDIE Model to Integrate High-Impact Practices into an Online Information Literacy Course. Communications in Information Literacy, 10(2), 264-282.

Hidayati, N. (2017). Efektivitas Pembelajaran Menggunakan Multimedia Interaktif (Adobe Flash CS6) terhadap Hasil Belajar Matematika Siswa Kelas V SDN Jurug Sewon. Trihayu: Jurnal Pendidikan Ke-SD-An, 3(3), 169-172.

Hsee, C. K., \& Ruan, B. (2016). The Pandora Effect: The Power and Peril of Curiosity. Psychological Science, 27(5), 659-666. https://doi.org/10.1177/0956797616631733.

Indah, F., Agoestanto, A., \& Woro, A. (2018). The students' critical thinking ability through problem posing learning model viewed from the students' curiosity. Unnes Journal of Mathematics Education, 7(3), 147-155. https://doi.org/10.15294/ujme.v7i3.25025.

Istiono, W. (2008). Education Game with Flash 8.0. Jakarta: Elex Media Komputindo.

Juminah, J., Sugiyo, S., \& Awalya, A. (2019). Information on Advanced Study Assisted by Adobe Flash Media to Increase Motivation for Advanced Studies. Jurnal Bimbingan Konseling, 8(1), 67-73.

Kesner Baruch, Y., Spektor-Levy, O., \& Mashal, N. (2016). Pre-Schoolers' Verbal and Behavioral Responses As Indicators of Attitudes and Scientific Curiosity. International Journal of Science and Mathematics Education, 14(1), 125-148. https://doi.org/10.1007/s10763-014-9573-6.

Molenda, M. (2015). In search of the elusive ADDIE model. Performance Improvement, 46(9), 9-16. https://doi.org/10.1002/pfi.

Mukminan. (2018). Dimensions and factors of contemporary geography learning climate at senior high school. Indonesian Journal of Geography, 50(1), 78-86. https://doi.org/10.22146/ijg.34567.

Nugroho, I. P. (2019). Memahami Rasa Ingin Tahu Remaja Ditinjau Berdasarkan Jenis Kelamin. Jurnal Bimbingan Dan Konseling Ar-Rahman, 5(1), 1-5. https://doi.org/10.31602/jbkr.v5i1.1675.

Oudeyer, P. Y., Gottlieb, J., \& Lopes, M. (2016). Intrinsic motivation, curiosity, and learning: Theory and applications in educational technologies. Brain Research, 229, 257-284. Retrieved from http://dx.doi.org/10.1016/bs.pbr.2016.05.005.

Pang, M. F., \& Runesson, U. (2019). The Learning study: recent trends and developments. International Journal for Lesson and Learning Studies, 8(3), 162-169. https://doi.org/10.1108/IJLLS-07-2019-093.

Peljko, Ž., Jeraj, M., Săvoiu, G., \& Marič, M. (2016). An empirical study of the relationship 
between entrepreneurial curiosity and innovativeness. Organizacija, 49(3), 172-182. https://doi.org/10.1515/orga-2016-0016.

Pluck, G., \& Johnson, H. (2011). Stimulating Curiosity To Enhance Learning. Education Sciences and Psychology, (2), 24-31. Retrieved from http://eprints.whiterose.ac.uk/74470/.

Prasetyo, E. G., Ginting, N. (2019). Pengembangan Media Pembelajaran Budaya Melayu engan Adobe Flash Berbasis Kearifan Lokal di Sekolah Dasar. Jurnal Basicedu, 3(2), $524-532$.

Rosmaiyadi, R. (2017). Analisis Kemampuan Berpikir Kritis Matematis Siswa Dalam Learning Cycle 7E Berdasarkan Gaya Belajar. AKSIOMA: Jurnal Program Studi Pendidikan Matematika, 6(1), 12. https://doi.org/10.24127/ajpm.v6i1.722.

Sanjaya, W. (2016). Strategi Pembelajaran Berorientasi Standar Proses Pendidikan. Jakarta: Kencana.

Schunk, D. H. (2012). Learning theories (teori teori pembelajaran perspektif pendidikan) edisi 6 (6th ed.). Yogyakarta: Pustaka Pelajar.

Sugiyono. (2015). Metode Penelitian Kuantitatif Kualitatif dan R\&D. Bandung: Alfabeta.

Ulva, V., Ibrohim, \& Sutopo. (2017). Mengembangkan Sikap Ilmiah Siswa SMP Melalui Pembelajaran Inkuiri Terbimbing pada Materi Ekosistem. Jurnal Pendidikan: Teori, Penelitian, Dan Pengembangan, 2(5), 622-626.

Vaughan, T. (2011). Multimedia: Making It Work Eighth Edition. In Vojnosanitetski pregled. Military-medical and pharmaceutical review (8th ed., Vol. 63). https://doi.org/10.2298/VSP0602169S.

Wahyudi, U. M. W., Wibawanto, H., \& Hardyanto, W. (2017). Pengembangan Media Edukatif Berbasis Augmented Reality untuk Desain Interior dan Eksterior. Innovative Journal of Curriculum and Educational Technology, 2. https://doi.org/10.15294/ijcet.v6i2.19337.

Zetriuslita, Z., Wahyudin, W., \& Dahlan, J. A. (2019). Association Among Mathematical Critical Thinking Skill, Communication, and Curiosity Attitude As the Impact of Problem-Based Learning and Cognitive Conflict Strategy (Pblccs) in Number Theory Course. Infinity Journal, 7(1), 15. https://doi.org/10.22460/infinity.v7i1.p15-24.

Zetriuslita, Z., Wahyudin, W., \& Jarnawi, J. (2017). Mathematical Critical Thinking and Curiosity Attitude in Problem Based Learning and Cognitive Conflict Strategy: A Study in Number Theory course. International Education Studies, 10(7), 65. https://doi.org/10.5539/ies.v10n7p65. 